The anaemia did not respond to haematinics, which is not surprising considering the deep-seated staphylococcal abscesses present at this stage; however, it is pertinent to remember that treatment with amphotericin B is associated with a normochromicnornocytic anaemia which appears early in the course of treatment and is characterized by the absence of reticulocytosis with neither marrow hyper- nor hypo-plasia (Utz et al., 1964). In this case, the thrombocytopenia was thought to be due to the septicaemia, although it is described as a late manifestation of the general marrow depression caused by amphotericin B. Thrombocytopenia is also described as an early, idiosyncratic effect of treatment with amphotericin B.

Melaena was present in this case from the twelfth to the twentieth day and was thought initially to be due to stress ulceration (Curling's Ulcer) and subsequently due to the massive infection of the gut with Candida.

\section{Acknowledgments}

My thanks to the nursing staff of the Children's Ward, North Staffordshire Royal Infirmary, for their skill in both looking after the child and the endless collection of specimens and tabulation of results, to Mr J. Grocott of the North Staffordshire Royal Infirmary for permission to use his material and to Mr C. R. Knappett of the North Staffordshire Royal Infirmary for his endless help with the bacteriology and in the preparation of this paper.

\section{References}

Andriole, V.T., Kravetz, H.M., Roberts, W.C. \& Utz, J.P. (1962) Candida endocarditis. Clinical and pathologic studies. American Journal of Medicine, 32, 251-285.
Dennis, D., Miller, M.J. \& Peterson, C.G. (1964) Candida septicaemia. Surgery, Gynaecology and Obstetrics, 119, 520-530.

De Vita, V.T., Utz, J.P., Williams, T. \& Carbone, P.P. 1966). Candida meningitis. Archives of Internal Medicine, 117, 527-534.

Goldman, J.A., Eckerling, B. \& Bassat, M.B. (1967) Fatal candida septicaemia developing after hysterectomy and transfusion. American Journal of Obstetrics and Gynecology, 98, 885-886.

Grocotr, J. (1962) Burns: a possible simplification of treatment. British Journal of Plastic Surgery, 15, 277-285.

HuRLEY, R. (1964) Acute disseminated (septicaemic) moniliasis in adults and children. Postgraduate Medical Journal, 40, 644-651.

HuRwich, B.J. (1966) Monilial peritonitis. Archives of Internal Medicine, 117, 405-408.

LEHNER, T. (1964) Systemic candidiasis and renal involvement. Lancet, i, 1414.

Lund, C.C. \& Browder, N.C. (1944) The estimation of areas of burns. Surgery, Gynaecology and Obstetrics, 79, 352-358.

Newsom, S.W.B., Lee, W.R. \& Rees, J.R. (1967) Fatal fungal infection following open-heart surgery. British Heart Journal, 29, 457-460.

Rifkind, D., Marchioro, T.L., Schneck, S.A. \& Hill, R.B. (1967) Systemic fungal infections complicating renal transplantation and immunosuppressive therapy. American Journal of Medicine, 43, 28-38.

UTZ, J.P., BenNeTt, J.E., BrandRiss, M.W., Butler, W.T. \& HILl, G.J. (1964) Amphotericin B toxicity. Combined Clinical Staff Conference at the National Institute of Health. Annals of Internal Medicine, 61, 334-354.

VINCE, 2. (1959) The spread of candida in infants and children. Medical Journal of Australia, 46, 143-145 and 145149.

Winner, H.I. \& Hurley, R. (1964) Candida albicans, 1st Edn, Churchill, London.

\title{
Pseudohyperaldosteronism induced by habitual ingestion of liquorice
}

\author{
A. M. Holmes \\ B.Sc., M.B., M.R.C.P. \\ J. YounG $\dagger$ \\ Technical Officer
}

\author{
P. K. MARRotT* \\ M.B., B.S., M.R.C.P̈. \\ E. Prentice $\dagger$ \\ Junior Technical Officer
}

Division of Metabolism, Department of Medicine, The Royal Infirmary, Manchester, M13 9WL

\section{Case report}

The patient, a 63-year-old man, was well until 1962 when mild diabetes was discovered. His blood pressure then was $105 / 80 \mathrm{mmHg}$. He was initially

\footnotetext{
*Present address: Registrar, Birch Hill Hospital, Rochdale.

†Present address: M.R.C. Blood Pressure Unit, Western Infirmary, Glasgow.
} 
admitted on 6 March to another hospital. The pulse rate was $44 / \mathrm{min}$, and the blood pressure $200 / 75$ $\mathrm{mmHg}$. A soft systolic bruit was audible at the cardiac apex and the liver was palpable 3 in. below the costal margin. Examination of the nervous system revealed slurred speech, marked proximal muscular weakness and absence of all tendon reflexes. The haemoglobin, white cell count, serum proteins, WR and CSF were normal. The blood sugar was $176 \mathrm{mg} / 100 \mathrm{ml}$; serum creatinine kinase $17 \cdot 3 \mathrm{mU} / \mathrm{ml}$; serum aldolase 59 units $/ \mathrm{ml} / \mathrm{hr}$; serum sodium $146 \mathrm{mEq}$, potassium $2.5 \mathrm{mEq}$, chloride 94 $\mathrm{mEq} / \mathrm{l}$ and blood urea $19 \mathrm{mg} / 100 \mathrm{ml}$. An ECG showed coupling due to premature beats following each normal beat. The chest X-ray was normal.

No specific treatment was given but tolbutamide was continued. He made a gradual recovery and 1 month later the serum levels of all muscle enzymes were normal.

On 6 June 1969 he was readmitted to the same hospital with a 3-week history of generalized weakness and a serum potassium of $1.7 \mathrm{mEq} / \mathrm{l}$. He confessed to eating large quantities of liquorice and was referred to the Manchester Royal Infirmary for further investigation.

He admitted to drinking up to 15 pints of beer daily until the onset of diabetes in 1962 and to eating at least $3 \frac{1}{2} \mathrm{lb}$ of liquorice weekly for the last 15-20 years. (This had been in the form of the root, liquorice sticks, 'Spanish draught' and commercially available sweets containing liquorice.) For 2 weeks prior to admission he had had diffuse muscle pain, tetanic cramps, thirst, polyuria and nocturia.

On examination he was a well-built man with greyish pigmentation of the skin. There was no reduction in body hair. His blood pressure was $200 / 70 \mathrm{mmHg}$ and his pulse $76 / \mathrm{min}$. A soft aortic mid-systolic bruit was audible but there was no oedema and no increase in jugular venous pressure. The liver was palpable 3 in. below the costal margin. He spoke with obvious dysarthria and had muscle weakness which was most marked proximally. All tendon reflexes were depressed and the plantar responses were flexor. Trousseau's sign was positive but Chvostek's sign was absent. The chest X-ray, haemoglobin, white cell count, ESR, serum proteins, bilirubin, thymol turbidity and alkaline phosphatase were normal. The serum calcium was $8.6 \mathrm{mg} / 100 \mathrm{ml}$, serum phosphorus $2.7 \mathrm{mg} / 100 \mathrm{ml}$ and serum magnesium $2.3 \mathrm{mg} / 100 \mathrm{ml}$. The serum amylase and lipase were normal. The bromsulphthalein excretion test was normal. There was evidence biochemically of muscle damage (see Table 1) in that the serum levels of muscle enzymes were elevated at the time of admission and subsequently returned to normal. Myoglobin was not detected in the serum or urine.

The serum sodium was $153 \mathrm{mEq} / \mathrm{l}$, serum potassium $2 \cdot 2 \mathrm{mEq} / 1$ and serum chloride $96 \mathrm{mEq} / 1$. The blood urea was normal. The blood $\mathrm{pH}$ was 7.47 and total venous $\mathrm{CO}_{2}$ was $36 \mathrm{mMol} / 1$ (see Fig. 1).

The creatinine clearance was $95 \mathrm{ml} / \mathrm{min}$. There was slight albuminuria (120 mg daily) and glycosuria. Microscopy of the urine showed no abnormality. There was no aminoaciduria and the acidifying capacity (Wrong \& Davies, 1959) was normal.

The serum iron was $270 \mu \mathrm{g} / 100 \mathrm{ml}$, iron binding capacity $330 \mu \mathrm{g} / 100 \mathrm{ml}$ and the percentage saturation was $82 \%$.

\section{Percutaneous liver biopsy (Dr P. Scheuer)}

There is heavy siderosis involving mostly liver cells but also reticuloendothelial cells. The appearances could be due to a persistently high iron intake but early idiopathic haemochromatosis is a more likely explanation.

Metabolic studies were started on 12 June 1969, 6 days after he had stopped eating liquorice. Fig. 1 illustrates the sequential changes in daily urinary output of sodium together with changes in body weight, serum sodium, potassium and total venous $\mathrm{CO}_{2} .24 \mathrm{hr}$ exchangeable sodium and potassium values at the beginning and end of the study are also shown. Although he was not receiving a fixed sodium intake, dietary estimates suggested that he was

TABLE 1. Improvement of enzymes concerned with muscle necrosis ( $n=$ normal values)

\begin{tabular}{|c|c|c|c|c|c|c|}
\hline & 12 June '69 & 16 June '69 & 18 June '69 & 23 June '69 & 30 June '69 & 7 July '69 \\
\hline Days after stopping liquorice & 6 & 10 & 12 & 17 & 24 & 31 \\
\hline $\begin{array}{l}\text { Serum creatine-phósphokinase (units/ } \\
\quad \mathrm{ml}(n=0-12)\end{array}$ & 172 & 12 & 6 & - & 3 & - \\
\hline Serum aldolase (units) $n=3-10$ & - & $8 \cdot 5$ & $16 \cdot 5$ & $10 \cdot 3$ & - & $3 \cdot 6$ \\
\hline $\begin{array}{l}\text { Serum lactic dehydrogenase (units/100 } \\
\text { ml) }(n=150-400)\end{array}$ & 535 & 425 & - & - & 250 & - \\
\hline SGOT (units/ml) $(n=6-40)$ & 96 & 28 & 12 & 10 & 11 & 9 \\
\hline SGPT (units/ml) $(n=5-35)$ & 59 & 66 & 54 & 39 & 43 & 22 \\
\hline
\end{tabular}


Exchangeable sodium $(\mathrm{mEq} / \mathrm{kg}) 62.3 \mathrm{KCl} 104 \mathrm{mEq} / \mathrm{day}$

Exchangeable 31.6 potassium ( $\mathrm{mEq} / \mathrm{kg}$ )
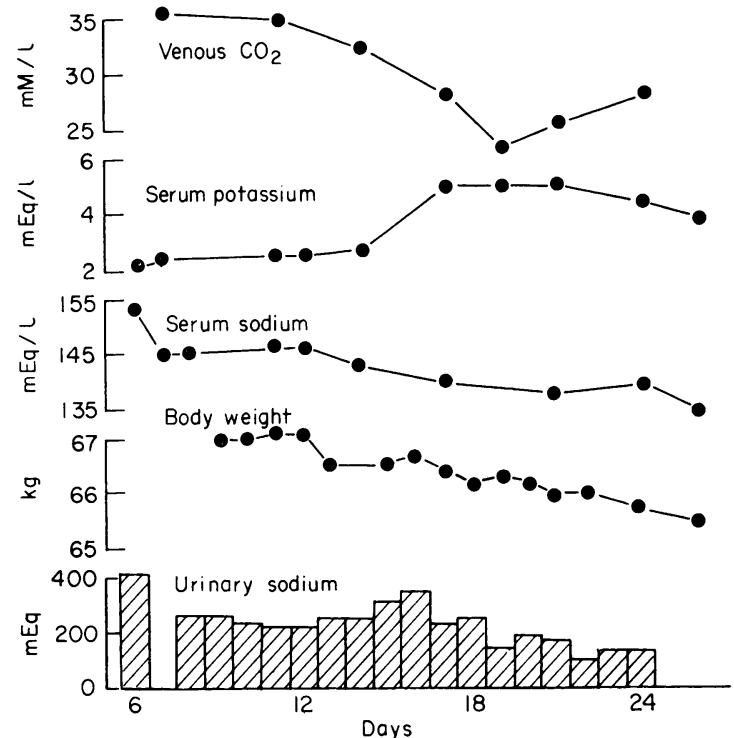

FIG. 1. Pattern of recovery after stopping the intake of liquorice. The normal values for total exchangeable sodium are $39.5-47.8 \mathrm{mEq} / \mathrm{kg}$ and for potassium $36.3 \pm$ $2.5 \mathrm{mEq} / \mathrm{kg}$.

taking about $150 \mathrm{mEq}$ daily. The loss of sodium in the urine was associated with a fall in body weight, serum sodium concentration and $24 \mathrm{hr}$ exchangeable sodium. His blood pressure which had been $200 / 70 \mathrm{mmHg}$ on admission had fallen to $140 / 70$ $\mathrm{mmHg}$ by 2 July. The serum potassium remained low with a urinary output of about $70 \mathrm{mEq} /$ day until potassium chloride supplements $(104 \mathrm{mEq}$ daily) were added, whereupon it rose to normal and the total venous $\mathrm{CO}_{2}$ fell. The exchangeable sodium and potassium data suggest that a net loss of 400 $\mathrm{mEq}$ sodium and net gain of $500 \mathrm{mEq}$ potassium had occurred between 17 June and 2 July (11th-26th day).

The results of plasma renin (Brown et al., 1964; normal range 4-20 units per litre) and aldosterone (Fraser \& James, 1968; normal range $<18 \mathrm{~m} \mu \mathrm{g} / 100$ $\mathrm{ml}$ ) measurements before treatment and during the period of recovery are given in Table 2 . The blood samples were all taken at 09.00 before the patient had risen. The initially low values gradually returned to normal during the period of study.

\section{Discussion}

A variety of reports relating sodium retention and hypokalaemia to the ingestion of liquorice and its extracts have been published previously. Revers (1946), using liquorice to treat peptic ulceration noticed hypertension and oedema in $20 \%$ of his patients. Liquorice extract was used as a flavouring agent for $p$-aminosalicylic acid in the treatment of pulmonary tuberculosis and many cases of hypokalaemia occurred, in some resulting in death (Cayley, 1950; Heard et al., 1950; Strong, 1951; Campbell \& Neufeld, 1951; Roussak, 1952). A deoxycortone-like action of liquorice was shown by Molhuysen et al. (1950) and was found to be due to ammonium salt of glycyrrhizic acid (Molhuysen et al., 1950; Borst et al., 1950). The salt imparts the flavour to liquorice.

An alcoholic beverage containing liquorice often used by alcoholics on the Continent, has caused severe hypokalaemia (Mollaret, Goulon \& Tournilhac, 1960; Jenny et al., 1961; Chodkiewicz, Clay \& Hécain, 1963). Salassa, Mattox \& Rosevear (1962) showed that the hypokalaemia of liquorice eaters was associated with diminished aldosterone excretion and was reversed by the aldosterone antagonist spironolactone. Conn, Rovner \& Cohen (1968) were able to depress plasma renin activity and aldosterone excretion by giving their patient ammonium glycyrrhizate.

Gross, Dexter \& Roth (1966) showed that the consumption of excessive quantities of liquorice may cause muscle damage and myoglobinuria. Their patient, a 45-year-old obese housewife, had also been given diuretics to help in weight reduction and she presented with marked proximal muscular weakness and muscle pain. Her urine was dark brown due to myoglobin and elevated serum levels of muscle enzymes, as well as profound hypokalaemia, were recorded. The urinary aldosterone excretion was within the normal range.

TABLE 2. Changes in plasma renin and aldosterone values after the liquorice intake was stopped

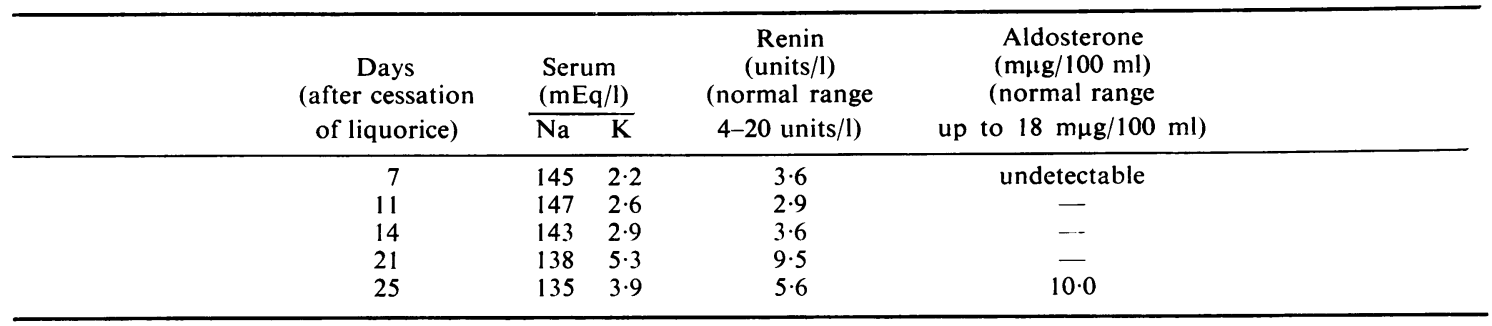


Our patient said he had been eating large quantities of liquorice for 15-20 years and, if this was correct, it is difficult to understand why he had hypokalaemic symptoms on only two occasions. The first episode in March 1969 may have been precipitated by the diuretics he had been given, but as oedema may be found in patients with severe potassium depletion it is likely that he was hypokalaemic before the diuretics were given. He had had no diuretic therapy prior to his second admission. The rise in $24 \mathrm{hr}$ exchangeable potassium and fall in exchangeable sodium during recovery pointed to previous potassium depletion and sodium retention.

Carbenoxolone sodium is a derivative of glycyrrhetinic acid the diglycuronide of which, glycyrrhizic acid, occurs in liquorice. A number of aldosterone-like side effects of this drug have been reported (Doll, Hill \& Hutton, 1965; Horwich \& Galloway, 1965; Turpie \& Thomson, 1965; Mohammed, Chapman \& Crooks, 1966; Forshaw, 1969). During carbenoxolone therapy, Baron et al. (1969) reported suppression of aldosterone secretion although in contrast to the present study and that of Conn et al. (1968) they did not find suppression of the plasma renin.

Mohammed et al. (1966) also described myoglobinuria due to severe muscle damage and Forshaw's patient (1969) had elevated levels of muscle enzymes in the serum and urinary findings suggestive of myoglobinuria. Myoglobinuria was not present in our patient despite marked elevation of the muscle enzymes. The reduction in plasma renin and aldosterone values was presumably due to the aldosterone-like action of liquorice causing sodium retention and suppression of endogenous aldosterone secretion, as suggested by Conn et al. (1968).

We can find no reports concerning any effect of liquorice or its derivative carbenoxolone on iron absorption. Liquorice sticks of the type the patient was consuming were analysed and found to contain $240 \mathrm{mg}$ iron per pound. A commercial sweet containing liquorice had an iron content of $43 \mathrm{mg}$ per pound. As the patient admitted to eating at least $3 \frac{1}{2} \mathrm{lb}$ of assorted types of liquorice per week he would have been ingesting between 24 and $120 \mathrm{mg}$ of iron daily. Over a period of 15 to 20 years excessive absorption of iron may have caused haemosiderosis. It is not possible for us to be dogmatic as to whether the increased iron stores in the liver were due to nutritional haemosiderosis comparable with that seen in the Bantu or to idiopathic haemochromatosis. There was no family history of diabetes or haemochromatosis.

Severe chronic potassium depletion may have contributed to his diabetic state (Conn, 1965;
Sagild, Anderson \& Andreason, 1961) since withdrawal of liquorice and the giving of potassium supplements resulted in hypoglycaemic symptoms, and tolbutamide therapy was no longer necessary on discharge from hospital.

\section{Acknowledgment}

The authors would like to thank Dr W. B. Matthews for permission to report this case.

\section{References}

Baron, J.H., Nabarro, J.D.N., Slater, J.D.H. \& Tuffley, R. (1969) Metabolic studies, aldosterone secretion rate and plasma renin after carbenoxolone sodium. British Medical Journal, 2, 793.

Borst, J.C.G., Blonhert, G., Molhuysen, J.A., Gerbrandy, J., Turner, K. \& DE VRIES, L.A. (1950) De uitscheiding van water en electrolyten gedurende het elmaal in onder invloed van succus liquiritiae. Acta clinica Belgica, 5, 405.

Brown, J.J., Davies, D.L., LeVer, A.F., Robertson, J.I.S. \& TREe, M. (1964) Estimation of plasma renin. Biochemical Journal, 93, 594.

Campbell, A.H. \& Neufeld, O.E. (1951) The cause of hypokalaemia (hypopotassaemia following para-aminosalicylate therapy). Medical Journal of Australia, i, 725.

CAYley, F.E. DE W. (1950) Potassium deficiency in $p$-aminosalicylic acid therarpy. Lancet, i, 447.

Chodkiewicz, J.P., Clay, J. \& Hecain, H. (1963) Deux nouvelles observations de paralysies avec hypokaliémie secondaire à l'ingestion excessive d'extrait de réglisse chez des éthyliques chroniques. Revue neurologique, 108, 324.

ConN, J.W. (1965) Hypertension, the potassium ion and impaired carbohydrate tolerance. New England Journal of Medicine, 273, 1135.

CONN, J.W., Rovner, D.R. \& CoHen, E.L. (1968) Licorice induced pseudoaldosteronism. Journal of the American Medical Association, 205, 80.

Doll, R., Hill, I.D. \& HutTon, C.F. (1965) Treatment of gastric ulcer with carbenoxolone sodium and oestrogens. Gut, 6, 19.

ForSHAW, J. (1969) Muscle paresis and hypokalaemia after treatment with Duogastrone. British Medical Journal, 2, 674.

FrASER, R. \& JAMES, V.H.T. (1968) Double isotope assay of aldosterone, corticosterone and cortisol in human peripheral plasma. Journal of Endocrinology, 40, 59.

Gross, E.G., DeXter, J.D. \& Roth, R.G. (1966) Hypokalaemic myopathy with myoglobinuria associated with licorice ingestion. New England Journal of Medicine, 274,602 .

Heard, K.H., Campbell, A.H., Hurley, J.J. \& Ferguson, E. (1950) Hypokalaemia complicating sodium paraamino-salicylate therapy for pulmonary tuberculosis. Medical Journal of Australia, ii, 606.

HoRWICH, L. \& GallowaY, R. (1965) Treatment of gastric ulceration with carbenoxolone sodium. Clinical and radiological evaluation. British Medical Journal, 2, 1274.

JenNy, M., Muller, A.F., FABre, J. \& MACH, R.S. (1961) Hypokaliémie et Alcalose par Ingestion Abusive d'extrait de Réglisse (Liquorice) et d'eau Bicarbonatié. Schweizerische medizinische Wochenschrift, 91, 869.

Mohammed, S.D., Chapman, R.S. \& Crookes, J. (1966) Hypokalaemia, flaccid quadruparesis and myoglobinuria with Carbenoxolone (Biogastrone). British Medical Journal, 1, 1581. 
Mollaret, P., Goulon, M. \& Tournilhac, M. (1960) Quadriplégie avec hypokaliémie et alcalose métabolique secondaire à l'ingestion massive et prolongée d'extrait de Réglisse chez un psychopathe ethylique et potomane. Bulletin de la Société médicale des hopitaux de Paris, 76, 491.

Molhuysen, J.A., Gerbrandy, J., DE VRIes, L.A., DE JoNG, J.C., Lenstra, J.B., TURNER, K.P. \& BORST, J.G.G. (1950) A liquorice extract with deoxycortone-like action. Lancet, ii, 381 .

ReVERS, F.E. (1946). Heeft succus liquirtae een genezende werking op de Maagzweer Nederl. Tijdschrift voor sociale geneeskunde, 90, 135.

RoussaK, N.J. (1952) Fatal hypokalaemic alkalosis with tetany during liquorice and P.A.S. therapy. British Medical Journal, 1, 360
Sagild, U., Anderson, V. \& Andreason, P.B. (1961) Glucose tolerance and insulin responsiveness in experimental potassium depletion. Acta medica Scandinavica, 169, 243.

Salassa, R.M., Mattox, V.R. \& Rosevear, J.W. (1962) Inhibition of the 'Mineralocorticoid' activity of licorice by spironolactone. Journal of Clinical Endocrinology, 22, 1156.

StroNG, J.A. (1951) Serum potassium deficiency during treatment with sodium, P.A.S. and liquorice extract. British Medical Journal, $2,998$.

TurPIE, A.G.G. \& Thomson, T.H. (1965) Carbenoxolone sodium in the treatment of gastric ulcer with special reference to side effects. Gut, 5,591 .

WRONG, O. \& DAVIES, H.E.F. (1959) The excretion of acid in renal disease. Quarterly Journal of Medicine, 28, 259.

\section{Acute lithium poisoning}

\author{
RAGHUNANDAN GAIND \\ M.B., F.R.F.P.S., M.R.C.P., D.P.M. \\ Guy's and St Olave's Hospitals, \\ London, S.E.16
}

Lithium was first discovered in 1818 by Arfvedson (1818) as an impurity in Swedish iron ore and, since then, traces of this element have been found widely distributed in salt beds and in vegetable and mineral matter. Although very much less soluble in water the compounds of lithium are like those of potassium in being depressant both to the myocardium and to the central nervous system.

Therapeutically, lithium carbonate and, more especially, effervescing lithium citrate, enjoyed a vogue towards the end of the last century for the treatment of chronic gout and rheumatism, until clinical trials showed the inefficacy of this regime. Then, just before the Second World War, lithium chloride was advocated as a salt substitute for those patients requiring a low-sodium diet, but this form of therapy was later abandoned following reports of severe lithium poisoning, some of the cases ending fatally. (Corcoran, Taylor \& Page, 1949; Hanlon et al., 1949; Stern, 1949).

The use of lithium salts in psychiatry began with the observation by Cade (1949) that they acted as sedatives on guinea pigs. Subsequently a number of reports (Baastrup, 1964; Baastrup \& Schou, 1967; Glesinger, 1954; Hartigan, 1963; Noack \& Trautner, 1951; Schou et al., 1954; Schou, 1968) testified to the value of lithium in the treatment of certain psychoses and, over the last 2 years, this form of therapy has been widely practised in the management of affective disorders, though the benefits prophylactically have come under severe criticism (Blackwell \& Shepherd, 1968; Saran, 1969).

Requests for reprints should be addressed to Dr B. M.

\author{
BriJ Mohan SARan \\ M.B., M.R.C.P., D.P.M. \\ Institute of Psychiatry, De Crespigny Park, \\ London, S.E.5
}

Lithium poisoning occurs when the element accumulates in the body as a result of intake exceeding excretion by the kidneys. At therapeutic serum levels there is often nausea, vomiting, diarrhoea, abdominal discomfort, lethargy, muscular weakness, sleepiness and tremor of the hands. Severe acute intoxication is characterized by ataxia, impairment of consciousness leading to coma and epileptiform fits. The latter may appear spontaneously, or on stimulation, and last a few seconds to half-a-minute. The eyes are wide open and there is hyperextension of the arms and legs, with gasping and grunting. The muscle tone is increased and the deep reflexes are brisk. (Schou, 1968). The EEG shows a decrease of alpha activity and the simultaneous appearance of theta and paroxysmal delta activity, mostly in the frontal region. Occasionally fast activity (beta) and sharp waves have been noted. (Mayfield \& Brown, 1966.) When this stage appears the serum lithium level is usually over $2 \mathrm{mEq} / \mathrm{l}$. However, in certain susceptible individuals severe side-effects have been noted at much lower levels. All these changes are reversible. In spite of the widespread use of lithium very few cases of acute over-dosage with suicidal intent have been reported. We present below such a case which presented a most unusual clinical picture.

\section{Case report}

Miss R.D., aged 45, was a woman of aboveaverage intelligence, possessing an honours degree in English and being a librarian by profession. From 1943 onwards she had been the victim of a depressive illness, having been in hospital on seven occasions 